\title{
US hegemony and regime change in Latin America
}

\author{
Luis L. Schenoni $\mathbb{P}^{\mathrm{a}}$ and Scott Mainwaring ${ }^{\mathrm{b}}$ \\ aniversity of Notre Dame, Notre Dame, IN, USA; ${ }^{\circ}$ Harvard University, Cambridge, MA, USA
}

\begin{abstract}
We contribute to the extensive literature on international influences on democratization and democratic breakdowns by conceptualizing hegemonic mechanisms of regime change and assessing them empirically. Our findings are based on a multi-methods approach and highlight the varying importance of hegemonic influences in post-1945 Latin America. We argue that US support for democratization was consistent in the wave of transitions to democracy that began in Latin America in 1978 and that it was decisive in many of these transitions. While past work has attributed responsibility to the US for the waves of democratic breakdowns from 1948 to 1956 and 1964 to 1976, an examination of the 27 breakdowns from 1945 to 2010 gives reason to doubt this interpretation. Future research could use these conceptual and methodological tools to explore the role of other powers in waves of democracy and authoritarianism.
\end{abstract}

KEYWORDS democracy; regime change; United States; hegemony; Latin America

\section{Introduction}

This article adds to the extensive literature on international influences on political regimes by conceptualizing what we call "hegemonic mechanisms" and using qualitative and quantitative tools to look at how the US impacted democratic transitions and breakdowns in Latin America since the end of World War II. We begin by taking stock of the literature on international effects on political regimes and by providing an empirical definition of our phenomenon of interest. Hegemonic mechanisms can be common in waves of regime change when the spatial reach of this regime change clusters within the hegemon's sphere of influence. Under such conditions, the hegemon can influence other countries' political regimes in many ways that range from direct military intervention to simply signalling potential support or even acquiescencing to authoritarian or democratic actors. Typically, however, hegemonic influence entails some agency on the ground through the application of economic or political tools to affect the balance of power between pro-regime groups and the opposition. Our framework suggests ways of inferring the presence of different hegemonic practices or mechanisms using a multi-method approach.

CONTACT Luis L. Schenoni Ilschenon@nd.edu 
Although this framework could be applied to any hegemon and regime type, we focus on US democracy promotion in Latin America since 1945. On empirical grounds, the article indicates that contrary to some scholarship, the US was not primarily responsible for the authoritarian waves that swept Latin America from 1948 to 1954 and from 1964 to 1977. Contrary to other scholarship, it suggests that US support for democratic transitions was far more consistent and relevant during the wave of democracy that began in 1978 .

We use a multi-method approach that combines crisps-set qualitative comparative analysis (csQCA), short case studies, and survival analysis to explore medium-n, small-n, and large-n samples. We begin by briefly analyzing US influence in all 37 democratic transitions and all 27 breakdowns in Latin America from 1945 to 2010 (Appendices II and III provide more detail). We then examine US influence in the early democratic breakdowns during the wave of authoritarianism in Latin America that began in 1948 and in the early transitions to democracy during the wave of democratization that began in 1978. Finally, a quantitative analysis suggests that US support for democratization, as measured by US aid flows, is a strong predictor of transitions.

This multipronged approach illuminates different aspects of the impact of US policy toward democracy and authoritarianism in Latin America, giving greater inferential leverage. The conclusions suggest that hegemonic mechanisms - in particular, US support for democratization-played an important role during Latin America's third wave of democratization. In contrast, the evidence suggests that the waves of authoritarianism from 1948-54 and 1964-77 were not the result of US hegemonic influence.

\section{Taking stock}

The scholarship on democratic transitions and breakdowns has proposed myriad explanations for the consistent finding that international influences and actors have an important effect on regime change. More than 20 years ago, Lawrence Whitehead suggested that authors converge on three recurrent international mechanisms, which he labelled "consent," "contagion," and "control." Since then, other scholars have proposed new typologies ${ }^{2}$ but none has taken hold definitively. (See online Appendix I for a summary of the literature). Several classifications propose a useful basic distinction between horizontal and hegemonic mechanisms.

Horizontal mechanisms emphasize bottom-up processes that take place among units that are relatively equal in formal status (that is, two or more independent countries). Most research on international influences in the field of comparative democratization focuses on them. ${ }^{3}$ Yet hegemonic mechanisms are frequently highly important in international politics, where power matters a great deal.

Hegemonic mechanisms are vertical or top-down mechanisms involving coercion and/or consent in which powerful states with vested interests in the proliferation of a particular regime type play a central role. Because of their superior power capabilities, hegemons can affect regimes in a wide variety of ways, from externally imposing them to supporting a certain outcome. Yet these mechanisms are often difficult to disentangle from horizontal factors. If hegemonic influences push in the same direction as horizontal diffusion, the former could be confounded with the intermediary role of smaller states, non-state actors, or institutions, and thus incorrectly attributed to diffusion. Conversely, hegemons could be simply intervening in an already moving process or 
triggering such a process involuntarily. Therefore, scholars need to disentangle hegemonic and horizontal influences before claiming or rejecting their presence.

\section{Hegemonic mechanisms: international power and regime change}

How can we know hegemonic influences when we see them? These mechanisms take place when a hegemon affects regimes within its sphere of influence by acting as source of demonstration, by actively promoting or supporting a regime, or even by militarily imposing one. The great variety of means by which hegemons can produce regime change or ensure regime stability in other countries makes it is necessary to talk of hegemonic mechanisms in the plural before specifying the logic of each individual mechanism. Yet they all share certain key characteristics.

First, hegemonic mechanisms require the existence of a state with considerably superior economic and military power vis-à-vis other states in their part of the world. Second, because the spatial reach of hegemonies has never been global, hegemonic mechanisms should occur within the hegemon's sphere of influence, that is, where it has enough linkages and leverage to influence the process. Consequently, regime transitions that cluster within a region with a strong power raise the possibility that hegemonic mechanisms could be at work.

Third, when hegemonic mechanisms are present, the first in a sequence of regime changes should start soon after a modification in the hegemon's foreign policy. Also, some actors or countries might be expected to transition first or more rapidly than others if they are more vulnerable to or specifically targeted by the new policy. Timing (temporal contiguity between policy change in the hegemon and the transition) and sequence (the order in which transitions occur, given how characteristics of the policy affect particular countries), therefore, in addition to geographical location, can strengthen the inference that the hegemon played a key role in the process.

Hegemons have many means to foster regime change in their area of influence. ${ }^{4}$ In some cases, they impose regimes through colonial rule or through invasion; these are foreign-imposed regime changes. ${ }^{5}$ Yet most of the time hegemons act indirectly by empowering or disenfranchising some domestic actors and tilting the balance in favour or against them, and hence swaying the balance between pro-regime actors and the opposition. By applying or threatening sanctions and offering or promising rewards - which can be moral, economic, military, and diplomatic - the hegemon can influence the domestic balance between pro-authoritarian and pro-democratic coalitions. $^{6}$

Usually, hegemons purposefully attempt to drive or support a process of regime change in other countries. This might mean activism in situ (for example, activities of the hegemon's officials on the ground) or some policy that directly rewards or penalizes local actors. However, a hegemon can also influence regime outcomes without necessarily displaying great agency. Because of their incommensurable power, hegemons can trigger a chain reaction simply through signals that could be interpreted by other actors as indicative of its future behaviour. Even the hegemon's acquiescence can have effects. ${ }^{7}$ Alternatively, if a hegemon supports a process of regime change in one country that started independently and is championed by other international or transnational actors, its support could act as a powerful source of diffusion. ${ }^{8}$ In these cases, since the observable implications of horizontal and hegemonic mechanisms overlap, it is necessary to explore both before adjudicating. 
In the remainder of this article, we turn to a most-likely case for hegemonic influence on political regimes: Latin America after 1945. Many scholars have documented that US policies about democracy and authoritarianism had an impact on Latin American regimes in the post-1945 era, ${ }^{9}$ yet few have done it using conceptual and methodological tools that could travel to other cases of hegemonic effects. ${ }^{10}$ We retell this story through the lens of hegemonic influences, treating the US and Latin America as one historical case where such mechanisms are sometimes at work, parsing some of these mechanisms, and using methods that illustrate ways in which scholars can test their observational implications.

Because Latin American waves of authoritarianism and democracy tended to cluster geographically and that the US is vastly more powerful than states in the region, our scope conditions are fulfilled. The next three sections explore to what extent the US supported transitions and breakdowns when they happened, provided an initial impulse for waves through demonstration, and acted consistently by offering incentives to domestic actors in this region.

\section{Promoting democracy on the ground: the role of US embassies}

In this section, we look at all 27 democratic breakdowns and 37 democratic transitions that took place in Latin America between 1945 and 2010. Our goal is to assess if the US government actively favoured regime change in those breakdowns and transitions and to assess whether US influence affected outcomes on the ground. We used secondary sources, primary documents, and interviews with diplomats. Because of spatial constraints, here we present a succinct summary of the evidence. Online Appendix III offers a complete list of these 37 transitions and 27 breakdowns and information about the US role in each case.

Even though some scholarship has placed considerable responsibility on the US for the waves of authoritarianism that swept Latin America from 1948 to 1956 and from 1964 to 1976, a case-by-case analysis of breakdowns suggests that this interpretation is too simplistic. The US manifested contradictory positions toward democracy and coups depending on its assessment of strategic risks. Some US presidents (for example, Eisenhower from 1953 until around 1958 and Nixon, 1969-74) did not prioritize supporting democracy in Latin America, but Washington never in principle preferred authoritarian regimes to democracy. The US supported coups in Guatemala (1954), Brazil (1964), the Dominican Republic (1965), Chile (1973), and Uruguay (1973). Moreover, the US put some pressure on the democratic government of Peru right before the 1948 coup, and American diplomats sympathized with military interventions in Costa Rica (1948), Panama (1948), Colombia (1949), Ecuador (1963), Bolivia (1964), and Argentina (1976). In these seven instances, a case could be made that hegemonic demonstration was at work. Previous work has shown that US signals that it would accept coups were associated with their occurrence. ${ }^{11}$ However, even taking such US signals into account - which often did not entail any agency on the ground - at most, the US favoured coups in 12 out of 27 democratic breakdowns. The waves of authoritarianism that rocked Latin America from 1948 to 1956 and from 1964 to 1976 were not a result of consistent US indifference toward democracy or support for authoritarianism; Washington opposed many coups.

As a general rule, when the US supported authoritarian regimes, it did so for strategic reasons, as a bulwark against a perceived communist threat during the Cold War. ${ }^{12}$ 
Washington remained neutral when coups did not provide a clear Cold War security advantage as in Panama (1948), Venezuela (1948), and Argentina (1966). The US also opposed coups when dictators might imperil US interests as in Peru (1962 and 1968) and Ecuador (1970) or when factional struggle between local elites weakened the US position, as in Honduras (1963) and Panama (1968). Finally, the US opposed all breakdowns that took place from the 1980s until 2010: Bolivia (1980), Peru (1992), Haiti (1999), and Honduras (2009). Out of 27 breakdowns in the 1945-2010 period, only five took place after 1978, suggesting that more consistent US support for democracy helped deter coups.

Support for democracy at critical junctures such as founding elections was far more consistent than support for authoritarian breakdowns. During the Truman years, the US supported democratic transitions in Guatemala (1945), Panama (1945), Argentina (1946), Brazil (1946), and Venezuela (1946), sometimes adamantly, due to the influence of "liberal cold warriors" at the high ranks of the Department of State. ${ }^{13}$

During most of the period from 1948 to 1977, conservative forces ruled US foreign policy toward democracy in Latin America (the Kennedy years, 1961-63, were an exception). However, looking at transitional episodes reveals that while the US refrained from voicing human rights concerns, supported some coups, and backed some authoritarian allies, it also supported democratic overtures every time they took place. Liberal US officials secured support for the transitions in Ecuador (1948) and Costa Rica (1949) despite the opposition of rising hawkish elements. ${ }^{14}$ Later on, several transitions took place in the mid-1950s - Bolivia (1956), Peru (1956), Panama (1956), Honduras (1957) - after President Dwight Eisenhower (1951-59) confronted the conservatives and concluded: "the United States must back democracies." ${ }^{15}$ After Vice-President Richard Nixon was attacked in Caracas, Venezuela, in May 1958, he suggested that the US should make even clearer its democratic preferences, offering "a formal handshake for dictators, an embraso (sic) for leaders in freedom," ${ }^{\prime 6}$ A brief honeymoon ensued. The US supported transitions to democracy in Argentina (1958), Colombia (1958) and Venezuela (1959).

During the Kennedy administration (1961-63), the resumption of pro-democracy US diplomacy once again coincided with the hesitancy of the militaries to retain power after the 1962 coups in Argentina and Peru, and their immediate return to tutelary democracy in 1963. Then in the late 1960s came a conservative shift in US policy toward democracy in Latin America. Washington used aid and loans to back the Ecuadoran transition (1968) and supported an electoral process in Honduras (1971), but failed to back these new governments, which rapidly collapsed.

The use of American hegemonic influence to sway domestic balances in favour of democratic forces became the norm after 1977. In some cases this policy to support democracy involved indirect - Nicaragua and El Salvador in the 1980s - and even direct - in the case of toppling Panamanian dictator Manuel Noriega in 1989 - military action. However, other sticks and carrots were far more common. In order to push an authoritarian regime to organize elections, the Department of State would lower its annual ratings on human rights. Congress and the president considered these ratings to limit or prohibit US foreign assistance and trade, and determine voting positions in international financial institutions. ${ }^{17}$ To support democratizers, the US developed preferential relations with existing democracies and mobilized pro-democracy coalitions in the UN and the OAS. In turn, the UN and OAS could apply pressure (for example, diplomatic segregation) to reassure certain actors (for example, business 
elites) that the new democracy would be supported and guarantee Latin American militaries the continuity of military cooperation after democratization. ${ }^{18}$

The more critical evidence of hegemonic activism was at the local level. US ambassadors voiced Washington's concerns, applauded moves toward liberalization, and sometimes granted material support to local actors via the CIA, USAID, and from 1983 on, the National Endowment for Democracy (NED). In Bolivia, Chile, Ecuador, Paraguay, and Peru, US ambassadors were key promoters of democratic transitions in critical moments during the late 1970s and 1980s. In Nicaragua and El Salvador, in the early 1980s, the US Embassy initially supported some democratic actors and some virulently authoritarian forces, but by the second half of the 1980s, US support for the latter waned. In Chile, the Dominican Republic, and Ecuador, officials such as the commander of the US Southern Command provided critical support during transitions. Even years after the transitions, the pressure and the intelligence coming from US embassies helped prevent several coup attempts from succeeding. ${ }^{19}$

In the 37 transitions that Mainwaring and Pérez-Liñán included from 1945 to 2010, the impact of US support for democratization varied greatly. The US was not a major actor in most democratic transitions before 1977, although it contributed to that outcome in Argentina (1946), Venezuela (1946 and 1959), Ecuador (1948 and 1968), Costa Rica (1949), Colombia (1958), and Peru (1963). In most other cases Washington formally supported the elections but followed a policy of non-intervention. This changes notably after 1977.

In his assessment of the role of US embassies in the third wave of democratization, Huntington concluded that it was critical in the Dominican Republic (1978), Ecuador (1979), El Salvador (1984), Guatemala (1986), Honduras (1982), Panamá (1990), Peru (1980) and Uruguay (1985) - eight cases - and a contributing factor in Bolivia (1979, 1982) and Chile (1990). ${ }^{20}$ The US also played a decisive role in transitions in Nicaragua (1984), Peru (1995), and Haiti (1995). ${ }^{21}$

If we put these assessments together, the US embassies played a relatively important role in 22 out of 37 cases of democratization. Among the cases where Washington was less important were Argentina (1958, 1963, 1973, and 1983), Brazil (1945-46 and 1985), and Mexico (1988), the three biggest economies in Latin America at the time. US impact was limited and tended to follow locally driven trajectories in these three cases, yet the US supported the transition in all of them. ${ }^{22}$

\section{A qualitative comparative analysis of US embassy support}

CsQCA is a data analysis technique suitable for medium-n contexts in which the researcher knows enough about each case to have an informed scholarly judgment. Given a set of relevant conditions that were concurrent with a certain outcome - in our case, breakdowns and transitions - csQCA uses Boolean algebra to identify the combinations that best describe the data. ${ }^{23}$ Thus, csQCA allows us to more systematically determine whether the support of US embassies for the successful regime coalition was consistently associated with cases of regime change. Consistent association does not show causation, but it reinforces the evidence from the cases and from the regression analysis later in this article.

We first analyse 27 episodes of democratic breakdown between 1945 and 2010 together with the 18 country-years with the highest probability of democratic collapse 
given their negative economic growth, high inflation, radicalization of the opposition, and a low support for democracy; these are alternative explanatory conditions or variables for breakdowns. In a second analysis, we include 37 democratic transitions together with the 22 country-years of authoritarian survival that faced the highest probability of transitioning given the aforementioned variables. Appendix II shows more details of the analysis.

Due to the existence of several logical reminders, none of these tests indicates that US Embassy support was a sufficient condition for regime change according to conventional use of csQCA. Yet while this condition does not appear as relevant in any configuration associated with breakdowns, the support of the US Embassy was the most consistent condition (1.00) and had the highest coverage (.83) in transitions to democracy. US Embassy support was present in $100 \%$ of the cases of democratization, and $83 \%$ of the time that the US Embassy supported a transition in a critical juncture, democratization followed. The fact that US support alone - not in any particular configuration with other factors - stands out, makes these results more reliable in a context of limited diversity. ${ }^{24}$ Substantively, this means that looking at most-likely cases of democratic transition, US Embassy support is more strongly associated with a democratic transition than any other factor deemed relevant in the literature.

This csQCA analysis illuminates two further points. First, even when American support for democracy was low during the Eisenhower, Johnson, Nixon, and first Reagan administrations, the analysis of specific transitions during those years shows that US embassies pushed for some important democratizing measures despite the general rhetoric of the government. During the Reagan administration, for instance, US support had a significant influence on transitions in Bolivia (1982), Honduras (1982), El Salvador (1984), and Nicaragua (1984). Second, looking at cases without a transition indicates that the effect of democracy promotion was neutralized in countries where US diplomatic activism was absent.

These findings underline the potential impact of US agency or at least US signalling: where the US Embassy did not support democratization, the authoritarian status quo always prevailed. Conversely, where a transition occurred and democracy prevailed, American embassies always supported democratization. Skeptics will correctly point out that Washington many times adapted to domestically driven processes and support for democratization. But even skeptics must recognize that while Washington opposed in one way or another nearly half of Latin American breakdowns, it supported, at least in intention, all 37 transitions. This is an important fact that has so far remained overlooked in the literature and for which we provide abundant evidence in Appendix III.

US policy presented blatant contradictions in some salient cases. In Nicaragua, El Salvador, and Guatemala, the US supported some highly authoritarian actors as well as some democratic ones during the 1980s. For example, although the US supported the Salvadoran military even as it slaughtered scores of thousands of its own citizens during the civil war of 1980-92, it also insisted that the Salvadoran government hold elections. The holding of elections beginning in 1982 ultimately was critical in the Salvadoran transition; it pushed the logic of critical actors on the Salvadoran right toward winning electoral support and forming a political party. Many scholars, activists, and policy makers have reasonably criticized US policy in Central America in the 1980s for not being more consistently pro-democratic and pro-human rights and for excessively tolerating and supporting authoritarian actors. Even in these cases, however, the US also generally supported democratic actors that ultimately prevailed in very 
fragile transitions. Almost invariably the US tended to adopt a clearer pro-democratic stance in the months preceding elections. Whether this was mere credit taking or an effective intervention remains debatable in some cases, but the consistency of this practice is notable.

The analysis in this section selected cases on the dependent variable, focusing on episodes where regime change occurred. Thus, it did not evaluate cases where US influence was present yet failed to produce the outcome. The statistical analysis in the last section uses a complete panel of Latin America 1945-2005 to overcome this limitation. ${ }^{25}$ But before proceeding with that analysis, we look at the role of the US in broader, regional tipping points in the following section.

\section{Starting waves in Latin America? Washington as a trigger}

Figure 1 reproduces Mainwaring and Pérez-Liñán's indicator for US policy toward authoritarianism and democracy in Latin America and their data on the number of competitive regimes out of 20 Latin American countries. It shows a remarkable correspondence between US support for democracy and its fate in this region.

As Figure 1 shows, abrupt changes in Washington's policy in 1948 and 1977 immediately preceded the beginning of sharp changes in regional patterns of democracy and authoritarianism. After attacking dictatorships and supporting democracies from 1944 to 1947 , in 1948, the US stopped withholding recognition of authoritarian governments. ${ }^{26}$ Subsequently, for most of the Cold War until 1977, the US offered meagre support for democracy and often supported authoritarian coups. ${ }^{27}$ Then, after the inauguration of Jimmy Carter, the US actively promoted democracy from 1977 to 1981 and from 1985 onwards. In this simplified story, 1948 and 1977 stand out as two critical junctures when clear changes in policy took place. ${ }^{28}$ For this reason, we explore

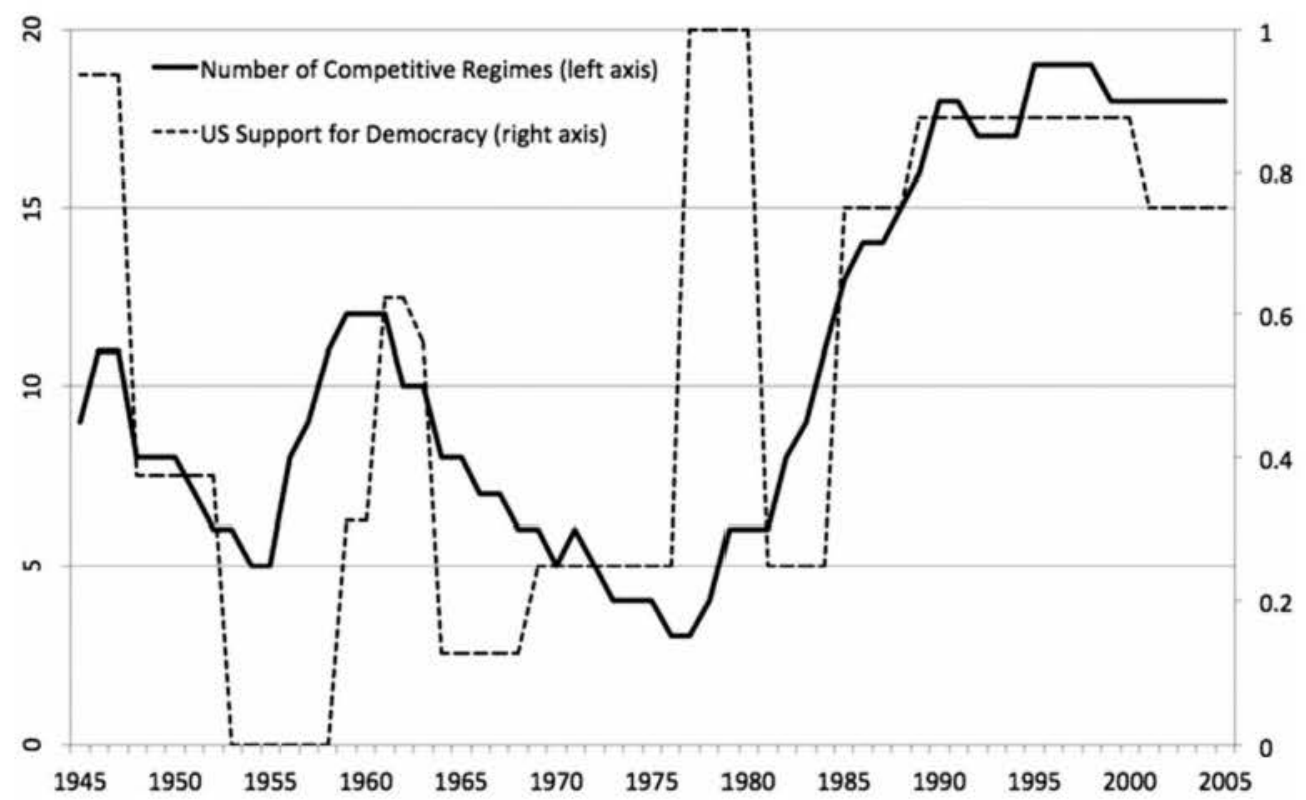

Figure 1. US Foreign Policy and Regime Change in Latin America. Source: Mainwaring and Pérez-Linán, Democracies and Dictatorships in Latin America, 87.

Note: US Support for Democracy measures Washington's pro-democratic stance based mostly on public statements and diplomatic positions (see Mainwaring and Pérez-Liñán, Democracies and Dictatorships in Latin America, Appendix 3.2). 
transitions that took place right after these critical junctures to weigh the impact these US policy changes had. Early cases matter for understanding diffusion and hegemonic influences because they are close to the beginning of a sequence. Due to temporal contiguity, they say more about triggering factors, and they are less "contaminated" by the simultaneous presence of diffusion. ${ }^{29}$ Dissemination effects are typically weaker in early cases; indeed, they are non-existent in the first case of a wave. ${ }^{30}$

The 1948 foreign policy change in Washington contributed to a counter wave of authoritarianism, but the US did not generally support the coups or prefer authoritarian regimes in the cases that immediately followed: 1948 coups against democratic governments in Costa Rica, Panama, Peru, and Venezuela. In none of these cases did the US clearly support coups against democratic governments. At most, the US signalled that it would accept military coups and work with "friendly" dictatorships, but this acquiescence was highly contradictory.

In Peru, the US failed to strengthen the democratic government, but it recognized the coup leader, Manuel Odría, only one month after he seized power. "US disinterest for democracy provoked a considerable popular backlash," ${ }^{31}$ but Washington never expressed support for the plotters and saw the outcome as unfortunate, yet inevitable. Assistant Secretary of State Edward Miller contemplated recommending sanctions against Peru after Odría's coup, but decided against them, fearing that they would worsen the situation "merely because we might not approve of this kind of government." 32

In Venezuela, the US Embassy weighed the pros and cons of opposing the coup against a new democratic government. Judith Ewell argues that although Washington opposed the coup in principle, it "apparently was prepared to accept a golpe both as inevitable and less harmful to US interests than any measures to assist (deposed President Rómulo) Gallegos would have been." ${ }^{33}$ While new dictator Marcos Pérez Jiménez "had no problem in gaining recognition from the Americans," "Washington viewed the new dictatorship negatively. Steven Schwartzberg notes that, "As was the case in Peru, neither the Cold War nor American policy was a significant factor in the overthrow of Venezuelan democracy." 35

Panama (1948) was a similar case in which the US acquiesced to a coup that overthrew a semi-democratic government. Similarly, the dynamics leading to constitutional crisis, a short civil war, and democratic breakdown in Costa Rica (1948) were overwhelmingly domestic. Washington "contributed significantly to the success of the democratic cause" one year later. ${ }^{36}$ Overall, US policy in the 1948 juncture was ambivalent and it rendered contradictory effects, being followed by roughly as many transitions as breakdowns in the subsequent decade.

The US role in triggering the early cases of the post-1978 wave of democratization is much clearer. The hegemon's policy shift, its agency on the ground, and the timing of the democratic transitions that followed clearly correspond. Out of the 20 Latin American countries, only Colombia, Costa Rica, and Venezuela were democratic in 1977. By 1990, Cuba and Haiti were the only unequivocal autocracies left. From 1977 to 1981 and from 1985 on, the US used a battery of means to punish dictators and reward democratizers. These policies were not always consistent in all countries, but the general orientation was clear. They tilted the incentives for domestic actors toward democracy.

Change toward a more pro-democracy policy began in a Subcommittee of the US Congress in 1974 and rapidly imbued the Democratic Party. ${ }^{37}$ Having campaigned on a human rights platform, Jimmy Carter took office in January 1977 and almost 
immediately began to emphasize human rights in US policy toward Latin America. Between 1978 and 1979 aid to Latin America dropped from \$210 million to \$54 million, penalizing only authoritarian regimes. ${ }^{38}$

The Latin American third wave started with four smaller and medium-sized autocracies in the region, where dictators were relatively weaker and Washington actively backed democratizers: the Dominican Republic (1978), Ecuador (1979), Peru (1980), and Bolivia (1982). Unlike in the four breakdowns reviewed above, US influence was of "very critical" importance in all these transitions (see Appendix III for more sources and historical detail about all 37 transitions to democracy and all 27 breakdowns from 1945 to 2010).

The US has impressive linkages and leverage in the Dominican Republic, so much so that some authors called the relationship an "informal empire." ${ }^{40}$ Many scholars agree that this "transition from without," support. ${ }^{42}$ Before the Dominican elections of May 16, 1978, the US sent a new, vehemently pro-democratic ambassador to the country. At US urging, observers from the Organization of American States (OAS) monitored the elections. On election night, when the military stopped the vote count to enable the incumbent dictator, Joaquín Balaguer (1966-78), to commit fraud, Secretary of State Cyrus Vance immediately issued harsh diplomatic protests. On May 19, Carter publicly called on Balaguer to "permit a free election or lose aid." ${ }^{\text {"3 }}$ The head of the US Southern Command personally telephoned the head of the Dominican army to let him know that the US military would oppose any coup to enable Balaguer to remain in office. The US measures were "crucial in dismantling the coup in the making." ${ }^{44}$ Under heavy US pressure to allow a fair vote count that resulted in the incumbent's defeat, the Dominican regime and military relinquished power and allowed for a transition to democracy.

Right after the Dominican transition, a US State Department memorandum established that "we will want to encourage the democratization processes in Bolivia, Ecuador and Peru ...." ${ }^{45}$ In 1979, the same procedures used in the Dominican Republic - that is, moving out ambassadors who had supported dictators and replacing them with ambassadors committed to free elections and human rights, deploying observers to monitor elections, discouraging local armed forces' intervention by the US military, and publicly pledging electoral integrity on the part of the US Secretary of State, threatening aid cuts - were applied to nudge the dictators toward holding elections and to secure the integrity of the Bolivian, Ecuadorian, and Peruvian elections.

In Ecuador, US diplomats acted to prevent coups against pro-democratic military leaders, discouraged authoritarian leaders from spoiling the elections, and conveyed Washington's support for democratic progress, most of the time as a condition for much needed financial and diplomatic assistance. ${ }^{46}$ The US Embassy strongly pressured the armed forces to return to civil rule. Pressure from Washington was high even several years before the transition. ${ }^{47}$ The US conditioned support for key priorities of Ecuador's military, ranging from arms transfers and fishing rights, to territorial claims against Peru and maritime claims, on progress toward democratization. The head of the Southern Command and the First Lady of the US, Rosalynn Carter, visited Peru to personally express US support for the electoral process to the junta on June 4, 1977. The First Lady was very insistent about supporting a transition to democracy, and she conveyed President Carter's direct support. According to Robert Pastor, who served on President Carter's National Security Council, "[In] Peru and Ecuador, she used every opportunity to reinforce the democratization process." 48 
US Ambassador (ret.) Edwin Corr, second in charge at the Quito Embassy at the time, recalled two episodes that illustrate the influence Washington exerted to favour pro-democratic actors. The first concerned a coup attempt by General Guillermo Durán, representative of the Army in the Junta, who wanted to derail a transition to democracy. Corr flew to the coast to warn Admiral Alfredo Poveda, the representative of the Navy in the Junta and the most pro-democratic figure among the three, about Durán's intentions. Corr's action might have prevented that coup. The second episode concerns the role the US played in discouraging the candidacy of Assad Bucaram - a leftist leader deemed unacceptable by the junta. Acting as mediators between the democratic and authoritarian soft-liners, US diplomats talked Bucaram out of running for office to prevent a military reaction and facilitate the transition. ${ }^{49}$

The Carter administration also supported democratization in Peru. As in Ecuador, the US used diplomatic support on key issues as a bargaining chip to get political liberalization. These included key issues at the top of the Peruvian military's agenda, such as the Law of the Sea, the Antarctic Treaty, and questions affecting their historical rivalry with Chile and Ecuador.

In Peru, Mrs Carter pressed dictator Francisco Morales Bermúdez (1975-80) hard to return to democracy in her visit in $1977 .{ }^{50}$ The US conditioned support for the Peruvian dictatorship in multilateral financial institutions on progress toward democratization. A US State Department secret cable detailed the many ways in which the US Embassy was engaging the military to secure their support for the transition, which it considered a "principal objective" of the US. One of these ways was through the use of military aid as a bargaining chip with the military. ${ }^{51}$

In an interview with one of the authors, Harry Shlaudeman, the US Ambassador to Peru from June 1977 to October 1980, stated that

US support in the IMF and with the World and Inter-American banks was critical in getting the military government through its terrible financial difficulties. That support was implicitly conditioned on progress toward democratization. During my farewell call on General Morales Bermúdez, he made a point of expressing eternal gratitude for President Carter's support (...) Perhaps our main contribution was in insisting on APRA's full participation and on its democratic credentials.... We did have a role in overcoming the long history of Aprista-military conflict, which otherwise could have scuttled the process. ${ }^{52}$

US success in supporting democratization in Bolivia was initially more elusive, but US pro-democratic support was steadfast. The Carter administration pressured dictator Hugo Banzer (1971-78) to open the regime, which it did by holding elections in 1978. The democratization process suffered setbacks along the way, with massive electoral fraud in 1978 and coups in 1978, 1979, and 1980. However, US pressure increased, contributing to a democratic outcome that probably would not have occurred otherwise. The Carter administration recalled its ambassador after the military launched a coup against a fledgling democratic government on July 17, 1980. Washington refused to recognize the military government and suspended $\$ 127$ million in assistance and aid. Then the Drug Enforcement Administration (DEA) implicated the García Meza dictatorship (July 1980 to August 1981) with drug trafficking. The US pushed the IMF, the World Bank, and other countries to isolate Bolivia and cut all financial support. The US established five conditions for a normalization of relations, among them "improved human rights [and] a reestablishment of democratic rule. ${ }^{\text {"53 }}$ García Meza, was forced out of office in August 1981. In late 1981 Corr, by then a well-known pro-democratic figure, was named Ambassador to Bolivia to "work behind the scenes to facilitate the 
transition." ${ }^{54}$ Months later, in October 1982, "with Corr playing an important role, the military agreed to hand over the government to the winner of the 1980 elections." ${ }^{15}$

The details of these cases indicate that change in the US human rights policy in 1977 was relevant for the actors involved in these first transitions and sent a clear message about how committed Washington was to supporting democratic leaders in the region. The profound impact this change in US policy would have on Latin American political regimes was not obvious at the time. Early transitions looked highly contingent, ${ }^{56}$ and it may have seemed implausible that the US had much to do with such a fragile and seemingly slow-moving process. Retrospectively, the change in American pro-democratic policies and its impact on the incentive structure of Latin American elites is clearer.

\section{Promoting democracy from Washington: the role of foreign aid}

This section aims to show that US foreign policy on the ground as proxied by foreign aid had a significant impact in the probability of a democratic transition, controlling for other relevant variables. We use survival analysis to test for the impact of US foreign aid policy in the average Latin American country. We replicate the main models in Mainwaring and Pérez-Liñán, ${ }^{57}$ replacing their measure of US support for democracy (Figure 1) with a country specific measure of US foreign economic and military aid.

Two observations are pertinent regarding the way in which Mainwaring and PérezLiñán coded US support for democracy in Latin America. First, their variable provides one value per year for the whole region. It therefore fails to reflect the US stance $v i s-\grave{a}$-vis specific Latin American countries, which probably biases the regression results in a conservative way by overlooking country-to-country variation. Second, measuring public statements may raise validity issues because actual policies, which are the result of complex political and bureaucratic processes, can be at odds with the statements of individual officials. Country-specific statements could be used to proxy signals, but not agency on the ground. ${ }^{58}$

We look at foreign aid instead. Almost all cases of effective US pressure on behalf of democracy involved the use of foreign aid, so it should provide a good proxy for US support for regime change. We look at both economic and military aid channelled by any US government agency, department, and office (US Overseas Loans and Grants Greenbook) as a per capita measure. We consider broader trends in aid to capture a larger set of uses. For instance, US support for authoritarian coups was often channelled through military assistance, and USAID was only one among many agencies and organizations through which pro-democratic funding was channelled. ${ }^{59}$ This variable ranges from zero to 210 US dollars per capita, with over $95 \%$ of the observations concentrating below the 100 US dollars per capita threshold.

In Tables 1 and 2, we analyse the correlation of US foreign assistance with the probability of a democratic transition among authoritarian regimes (Table 1) and of a democratic breakdown among democracies (Table 2) for the 1945-2005 period. We replicate the main survival models in Mainwaring and Pérez-Liñán, using their models 4.4 .5 and 4.2.5 as a baseline (first column) that we then modify by introducing the variable for US aid. ${ }^{60}$

The positive coefficients for US foreign assistance are consistent with the case studies. The US offered aid to authoritarian governments on the condition that they were making progress toward democratization. The US cut aid to authoritarian 
Table 1. Survival models for authoritarian regimes (transitions).

\begin{tabular}{|c|c|c|c|c|}
\hline & $\begin{array}{c}4.2 .5 \\
(1945-2005)\end{array}$ & $\begin{aligned} & 4.2 .5 \\
+ & \text { US aid }\end{aligned}$ & $\begin{array}{c}\text { US aid } \\
(1945-2005)\end{array}$ & $\begin{array}{c}\text { US aid } \\
(1977-2005)\end{array}$ \\
\hline \multicolumn{5}{|l|}{ Actors' preferences } \\
\hline Radicalism (ruler and allies) & $\begin{array}{r}-1.150^{*} \\
(.588)\end{array}$ & $\begin{array}{r}-1.410 \\
(.972)\end{array}$ & $\begin{array}{r}-1.069 \\
(.753)\end{array}$ & $\begin{array}{c}-.082 \\
(.650)\end{array}$ \\
\hline Radicalism (opposition) & $\begin{array}{l}2.284^{* * * *} \\
(.817)\end{array}$ & $\begin{array}{c}2.146^{*} \\
(1.128)\end{array}$ & $\begin{array}{l}1.449^{* *} \\
(.715)\end{array}$ & $\begin{array}{c}.837 \\
(.768)\end{array}$ \\
\hline Normative preferences (all) & $\begin{array}{l}3.228^{* * *} \\
(.634)\end{array}$ & $\begin{array}{l}3.172^{* * *} \\
(.739)\end{array}$ & $\begin{array}{l}3.007^{* * *} \\
(.567)\end{array}$ & $\begin{array}{l}2.370^{*} \\
(1.188)\end{array}$ \\
\hline \multicolumn{5}{|l|}{ International factors } \\
\hline U.S. policy & $\begin{array}{l}1.053^{*} \\
(.583)\end{array}$ & $\begin{array}{l}.886 \\
(.838)\end{array}$ & - & - \\
\hline Per capita foreign assistance (US) & - & $\begin{array}{l}.016^{* *} \\
(.006)\end{array}$ & $\begin{array}{l}.020^{* * * *} \\
(.005)\end{array}$ & $\begin{array}{l}.015^{* * *} \\
(.006)\end{array}$ \\
\hline Region, $t-1$ & $\begin{array}{l}3.984^{* *} \\
(1.736)\end{array}$ & $\begin{array}{c}3.542 \\
(2.259)\end{array}$ & - & - \\
\hline Polity outside the region, $t-1$ & $\begin{array}{c}-.070 \\
(.163)\end{array}$ & $\begin{array}{c}.045 \\
(.230)\end{array}$ & $\begin{array}{l}.263 \\
(.175)\end{array}$ & $\begin{array}{l}-.133 \\
(.134)\end{array}$ \\
\hline \multicolumn{5}{|l|}{ Alternative explanations } \\
\hline Per capita GDP, In $t-1$ & $\begin{array}{l}-.379 \\
(.575)\end{array}$ & $\begin{array}{l}-.673 \\
(.766)\end{array}$ & $\begin{array}{c}-.463 \\
(.604)\end{array}$ & $\begin{array}{c}-1.312^{* * *} \\
(.473)\end{array}$ \\
\hline Industrial labour, $t-1$ & $\begin{array}{l}.116^{* * *} \\
(.055)\end{array}$ & $\begin{array}{r}.189 \\
(0.46)\end{array}$ & $\begin{array}{l}.171 \\
(.061)\end{array}$ & $\begin{array}{l}.145^{* *} \\
(.067)\end{array}$ \\
\hline Oil and mineral exports & $\begin{array}{c}.634 \\
(.656)\end{array}$ & $\begin{array}{c}.085 \\
(1.116)\end{array}$ & $\begin{array}{l}1.045 \\
(.829)\end{array}$ & $\begin{array}{l}.101 \\
(.407)\end{array}$ \\
\hline Growth, 10 years & $\begin{array}{c}-14.481 \\
(14.699)\end{array}$ & $\begin{array}{c}-28.996^{* *} \\
(13.577)\end{array}$ & $\begin{array}{c}-30.786^{* * *} \\
(11.647)\end{array}$ & $\begin{array}{r}-19.907 \\
(14.650)\end{array}$ \\
\hline Age of the regime & $\begin{array}{c}.132 \\
(.126)\end{array}$ & $\begin{array}{l}.307^{* *} \\
(.152)\end{array}$ & $\begin{array}{l}.350^{* *} \\
(.144)\end{array}$ & $\begin{array}{c}.233 \\
(.189)\end{array}$ \\
\hline Age of the regime $\wedge 2$ & $\begin{array}{c}-.004 \\
(.005)\end{array}$ & $\begin{array}{l}-.010 \\
(.006)\end{array}$ & $\begin{array}{r}-.012^{*} \\
(.006)\end{array}$ & $\begin{array}{c}-.009 \\
(.008)\end{array}$ \\
\hline Age of the regime $\wedge 3$ & $\begin{array}{l}.000 \\
(.000)\end{array}$ & $\begin{array}{c}.000 \\
(.000)\end{array}$ & $\begin{array}{l}.000 \\
(.000)\end{array}$ & $\begin{array}{l}.000 \\
(.000)\end{array}$ \\
\hline Intercepts (Thresholds) & & & & \\
\hline Semi-democracy & $\begin{array}{c}5.042 \\
(3.634)\end{array}$ & $\begin{array}{c}5.250 \\
(3.989)\end{array}$ & $\begin{array}{c}4.583 \\
(3.671)\end{array}$ & $\begin{array}{c}-2.842 \\
(2.576)\end{array}$ \\
\hline Democracy & $\begin{array}{c}6.229 \\
(3.640)\end{array}$ & $\begin{array}{c}6.443 \\
(3.994)\end{array}$ & $\begin{array}{c}5.713 \\
(3.705)\end{array}$ & $\begin{array}{c}-1.840 \\
(2.496)\end{array}$ \\
\hline Intercept variance & $\begin{array}{l}.360 \\
(.656)\end{array}$ & $\begin{array}{c}.995 \\
(1.612)\end{array}$ & $\begin{array}{l}.373 \\
(.675)\end{array}$ & $\begin{array}{c}0.000 \\
(0.000)\end{array}$ \\
\hline Pseudo $R^{2}$ & 0.17 & 0.20 & 0.19 & 0.16 \\
\hline$N$ & 576 & 564 & 564 & 181 \\
\hline
\end{tabular}

Note: Entries are random-effects ordered logistic coefficients (standard errors). The dependent variable is trichotomous and is coded " 0 " if an authoritarian regime persisted that year and " 1 " or " 2 " if a transition to semi-democracy or a transition to democracy occurred, respectively; ${ }^{* * *} p<0.01 ;{ }^{* *} p<0.05 ;{ }^{*} p<0.1$. Source: Mainwaring and Pérez-Liñán, Democracies and Dictatorships in Latin America, 104 and US Overseas Loans and Grants Greenbook.

regimes that were not moving toward democracy. Thus, greater US aid is associated with a greater probability of a transition to democracy. The second column in Table 1 shows that when US foreign assistance proxies for US pro-democracy policies, the association between regional diffusion and US policy preferences, on the one hand, and democratic transitions, on the other, disappears. As measured by the p-value, US policy as proxied by foreign aid has a stronger association with democratic transitions than the regional diffusion variable. In column 3, we take out the variables for regional diffusion and US policy preferences and retain US foreign assistance. Compared to the original model (column 1), the model in column 3 slightly increases 
Table 2. Survival models for democratic regimes (breakdowns).

\begin{tabular}{|c|c|c|c|c|}
\hline & $\begin{array}{c}4.4 .5 \\
(1945-2005)\end{array}$ & $\begin{aligned} & 4.4 .5 \\
&+ \text { US aid } \\
&\end{aligned}$ & $\begin{array}{c}\text { US aid } \\
(1945-2005)\end{array}$ & $\begin{array}{c}\text { US aid } \\
(1948-1976)\end{array}$ \\
\hline \multicolumn{5}{|l|}{ Actors' preferences } \\
\hline Radicalism (ruler and allies) & $\begin{array}{l}1.034 \\
(.989)\end{array}$ & $\begin{array}{c}1.046 \\
(1.043)\end{array}$ & $\begin{array}{c}1.432 \\
(1.061)\end{array}$ & $\begin{array}{l}1.832^{* *} \\
(.715)\end{array}$ \\
\hline Radicalism (opposition) & $\begin{array}{r}-.686 \\
(.690)\end{array}$ & $\begin{array}{c}-.681 \\
(.734)\end{array}$ & $\begin{array}{c}-.648 \\
(.914)\end{array}$ & $\begin{array}{l}-.773 \\
(1.208)\end{array}$ \\
\hline Normative preferences (all) & $\begin{array}{l}-2.698^{* *} \\
(1.100)\end{array}$ & $\begin{array}{l}-2.755^{* *} \\
(1.234)\end{array}$ & $\begin{array}{l}-2.981^{* *} \\
(1.492)\end{array}$ & $\begin{array}{c}-2.701 \\
(1.971)\end{array}$ \\
\hline \multicolumn{5}{|l|}{ International factors } \\
\hline U.S. policy & $\begin{array}{r}-.829 \\
(.641)\end{array}$ & $\begin{array}{l}-.512 \\
(.934)\end{array}$ & - & - \\
\hline Per capita foreign assistance (US) & - & $\begin{array}{r}-.010 \\
(.007)\end{array}$ & $\begin{array}{l}-.013^{* * *} \\
(.004)\end{array}$ & $\begin{array}{r}-.019 \\
(.015)\end{array}$ \\
\hline Region, $t-1$ & $\begin{array}{l}-4.376^{* * *} \\
(1.933)\end{array}$ & $\begin{array}{l}-5.087^{* *} \\
(2.346)\end{array}$ & - & - \\
\hline Polity outside the region, $t-1$ & $\begin{array}{r}-.430^{*} \\
(.249)\end{array}$ & $\begin{array}{c}-.512 \\
(.352)\end{array}$ & $\begin{array}{l}-.822 \\
(.244)\end{array}$ & $\begin{array}{r}-1.024 \\
(.660)\end{array}$ \\
\hline \multicolumn{5}{|l|}{ Alternative explanations } \\
\hline $\begin{array}{l}\text { Per capita GDP, } \\
\qquad \text { In } t-1\end{array}$ & $\begin{array}{l}.307 \\
(.531)\end{array}$ & $\begin{array}{l}.145 \\
(.570)\end{array}$ & $\begin{array}{c}.039 \\
(.666)\end{array}$ & $\begin{array}{l}.407 \\
(.557)\end{array}$ \\
\hline Industrial labour, $t-1$ & $\begin{array}{r}-.000 \\
(.047)\end{array}$ & $\begin{array}{l}.008 \\
(.053)\end{array}$ & $\begin{array}{c}.024 \\
(.051)\end{array}$ & $\begin{array}{c}-.063 \\
(.059)\end{array}$ \\
\hline Oil and mineral exports & $\begin{array}{r}-.976 \\
(.711)\end{array}$ & $\begin{array}{r}-.695 \\
(.735)\end{array}$ & $\begin{array}{c}-.622 \\
(.858)\end{array}$ & $\begin{array}{c}-3.49^{* * *} \\
(.997)\end{array}$ \\
\hline Growth, 10 years & $\begin{aligned} & 6.955 \\
&(12.856)\end{aligned}$ & $\begin{array}{r}8.569 \\
(16.513)\end{array}$ & $\begin{array}{l}24.941^{* *} \\
(10.895)\end{array}$ & $\begin{array}{c}.785 \\
(28.228)\end{array}$ \\
\hline Presidential powers & $\begin{array}{l}-.247^{* * *} \\
(.049)\end{array}$ & $\begin{array}{l}-.302^{* * *} \\
(.051)\end{array}$ & $\begin{array}{l}-.238^{* * *} \\
(.055)\end{array}$ & $\begin{array}{r}-.396^{*} \\
(.201)\end{array}$ \\
\hline Multipartism, $t$ & $\begin{array}{l}.445 \\
(.643)\end{array}$ & $\begin{array}{l}.489 \\
(.659)\end{array}$ & $\begin{array}{c}.751 \\
(.543)\end{array}$ & $\begin{array}{l}-.981 \\
(1.151)\end{array}$ \\
\hline Semi-democracy, $t-1$ & $\begin{array}{l}2.305^{* * *} \\
(.622)\end{array}$ & $\begin{array}{l}2.550^{* * *} \\
(.760)\end{array}$ & $\begin{array}{l}2.107^{* * *} \\
(.668)\end{array}$ & $\begin{array}{l}2.716^{* * *} \\
(.817)\end{array}$ \\
\hline Age of the regime & $\begin{array}{c}.213 \\
(.158)\end{array}$ & $\begin{array}{r}197 \\
(.196)\end{array}$ & $\begin{array}{c}.175 \\
(.201)\end{array}$ & $\begin{array}{c}.573 \\
(.414)\end{array}$ \\
\hline Age of the regime $\wedge 2$ & $\begin{array}{l}-.008 \\
(.008)\end{array}$ & $\begin{array}{r}-.006 \\
(.011)\end{array}$ & $\begin{array}{l}-.004 \\
(.011)\end{array}$ & $\begin{array}{c}-.036 \\
(.026)\end{array}$ \\
\hline Age of the regime $\wedge 3$ & $\begin{array}{c}.000 \\
(.000)\end{array}$ & $\begin{array}{c}.000 \\
(.000)\end{array}$ & $\begin{array}{c}.000 \\
(.000)\end{array}$ & $\begin{array}{c}.000 \\
(.000)\end{array}$ \\
\hline Constant & $\begin{array}{c}-2.202 \\
(5.258)\end{array}$ & $\begin{array}{l}-.329 \\
(5.368)\end{array}$ & $\begin{array}{c}-3.414 \\
(5.955)\end{array}$ & $\begin{array}{c}-1.234 \\
(6.043)\end{array}$ \\
\hline Intercept variance & $\begin{array}{c}0.000 \\
(0.000)\end{array}$ & $\begin{array}{c}0.000 \\
(0.000)\end{array}$ & $\begin{array}{c}0.000 \\
(0.000)\end{array}$ & $\begin{array}{c}0.000 \\
(0.000)\end{array}$ \\
\hline Pseudo $R^{2}$ & 0.35 & 0.37 & 0.33 & 0.37 \\
\hline$N$ & 644 & 635 & 635 & 218 \\
\hline
\end{tabular}

explanatory power despite being a bit more parsimonious. Finally, column 4 shows that, as measured by the p-value, the US aid variable was statistically more significant than domestic actors' preferences in the 1977-2005 period.

Table 2 applies the same procedure to the survival of democracy. In line with the qualitative findings in the last section, the association of US policy with democratic breakdowns is less impressive. The second column shows that the predictive power of regional diffusion per se is not overcome by adding the variable for US aid. Column 3 shows that overall (1945-2005) greater US foreign assistance is associated with a reduced probability of a democratic breakdown. The US did not consistently support 
democracy in the 1948-76 period, so in Column 4 there is more variance in the association of foreign aid with democratic breakdown, resulting in much larger standard errors.

The conclusion from these tables is that US foreign assistance is strongly associated with the third wave of democratization in Latin America. US aid or its lack thereof did not cause regime change by itself, but it served as a proxy for US support for democracy and opposition to authoritarianism. Using this proxy, from 1977 to 2005 hegemonic effects were significantly associated with authoritarian breakdown and democratic stability in Latin America. Conversely, results for 1948-1976 do not support the idea that the US systematically bolstered authoritarian regimes. Although it goes beyond the goals of this article to explain the waves of authoritarianism from 1948 to 1954 and 1964 to 1977, the polarizing effects of the Cold War, especially after the Cuban revolution, loom large in any understanding of these regional trends. The US was the main actor in the Guatemalan coup of 1954 and it strongly influenced other outcomes, but the evidence suggests that it did not unleash the waves of authoritarianism that began in 1948 and 1964.

\section{Conclusions}

Hegemonic actors have a powerful effect on regime change and stability in their regions of influence. Our findings comport with Levitsky and Way's work on competitive authoritarianism, which considers Western pressure an important factor leading to the rise of competitive regimes in the post-Cold War era. We show that hegemonic mechanisms have been present in Latin America and were particularly relevant during the wave of democratization that began in the late 1970s.

We provide a conceptualization and systematic empirical test of hegemonic mechanisms, a form of international influence on regime outcomes that is sometimes overshadowed by other international factors such as demonstration and diffusion. Hegemons affect political regimes in countries within their sphere of influence. When a hegemon exists and regional clustering of regime change occurs in the hegemon's sphere of influence (that is, transitions take place after a change in the hegemon's behaviour), it is likely that the regime outcome is affected by the signals or active agency of this bigger state. The massive relative power of the US in the western hemisphere and the geographical clustering of Latin American waves are easy to prove, so we use a multi-methods approach to explore whether and how the US acted as a trigger and driver of regime change.

First, the csQCA analysis of 27 democratic breakdowns and 37 transitions to competitive regimes between 1945 and 2010 showed that US embassies signalled pro-democratic preferences whenever transitions took place. US support for democratization was not consistently decisive, but it existed in all cases - a notable finding. Second, the analysis of two critical junctures for the whole region suggests that the triggering effect of Washington's policy change, although unclear and weak in 1948, was far clearer and sustained in the 1977 juncture. Third, our replication of the main survival models in Mainwaring and Pérez-Liñán demonstrates that US foreign aid was systematically related to democratic transitions in the post-1977 era. Put together, this multi-method approach offers three solid and interlinked pieces of evidence suggesting a prominent role of hegemonic influence in Latin America during the third wave of democratization.

\section{Notes}

1. Whitehead, The International Dimension. 
2. Weyland, Making Waves; Pevehouse, Democracy from Above.

3. This is probably because the assumption of unit homogeneity has paired well with statistical techniques. See Brinks and Coppedge, "Diffusion Is No Illusion".

4. Huntington, The Third Wave, 93.

5. Reiter, "Foreign Imposed Regime Change"; Owen, The Clash of Ideas.

6. Pridham, Encouraging Democracy, 7; Mainwaring and Pérez-Liñán, Democracies and Dictatorships, 212-213.

7. In these cases, the hegemon could even provoke a wave unintentionally or by omission. The wave of democratization in Eastern Europe beginning in 1989 provides a good example (Brown, "Transnational Influences").

8. Diffusion arguments need to say something about networks (Weyland, Making Waves, 39). In regions such as 20th century Latin America, diffusion networks - social, economic, intergovernmental, technocratic and informational (Levitsky and Way, Competitive Authoritarianism, 43) provide thicker links with the US than with any other country.

9. Middlebrook and Rico, The United States; Kryzanek, US-Latin American Relations; Lowenthal, Exporting Democracy; Carothers, In the Name of Democracy; Smith, Talons of the Eagle; Atkins, Latin America and the Caribbean; Pastor, Exiting the Whirlpool; Schoultz, Beneath the United States. See Appendix III for a more exhaustive bibliography.

10. For exceptions see Mainwaring and Pérez-Liñán, Democracies and Dictatorships, and Levitsky and Way, Competitive Authoritarianism, 130-179.

11. Thyne, "Supporter of Stability".

12. Smith, Talons of the Eagle, 188.

13. Schwartzberg, Democracy and U.S. Policy in Latin America.

14. "In both Ecuador and Costa Rica, American policy contributed significantly to the success of the democratic cause." Schwartzberg, Democracy and U.S. Policy in Latin America, 168. See also p. xv.

15. Rabe, Eisenhower and Latin America, 86.

16. Ibid., 104 .

17. After Mexico defaulted in 1982, triggering the Latin American debt crisis, the US had increasing financial leverage vis-à-vis its Latin American neighbours. See Levitsky and Way, Competitive Authoritarianism, 40-43.

18. Pevehouse, Democracy from Above.

19. Pastor, Exiting the Whirlpool, 42-48; Huntington, The Third Wave, 95; Atkins, Latin America and the Caribbean; Handelman and Sanders, Military Government.

20. Huntington, The Third Wave, 98.

21. Mainwaring and Pérez-Liñán, Democracies and Dictatorships in Latin America, 229; see also Lowenthal, Exporting Democracy, and Pevehouse, Democracy from Above, 127-138.

22. Robinson, "Capitalist Polyarchy," 315.

23. We use csQCA in this descriptive sense only. See Rioux and Ragin, Configurational Comparative Methods, 15.

24. Seawright, "Comment".

25. For why selecting on the dependent variables is a good initial approach see Goertz, Multimethod Research, 58-66. The need to combine different approaches to inference is suggested there and in Coppedge, Democratization and Research Methods. We use 2005 as an end date for the statistical analysis to replicate the models in Mainwaring and Pérez-Liñán, Democracies and Dictatorships in Latin America, 103-115.

26. Schwartzberg, Democracy and U.S. Policy in Latin America, 189.

27. The years from 1959 to 1963 were a short-lived exception.

28. See Gunitsky, "From Shocks to Waves".

29. As Weyland puts it: "the frontrunner's success encourages them [democratizers] to challenge their own rulers..." and it is precisely in those forerunners that "the inflection stemming from the initial trigger is usually clear" (Weyland, Making Waves, 1, 17). "The demonstration effect obviously cannot affect the first democratization. The early democratizations of the third wave were the result of triggers, not snowballs" (Huntington, The Third Wave, 104).

30. Appendix III provides more documentation in support of the claims in this section.

31. McClintock and Vallas, "The United States and Peru," 10.

32. Schwartzberg, Democracy and U.S. Policy, 120. 
33. Ewell, "Venezuela and the United States," 152.

34. Romero and Kelly, "United States and Venezuela," 17.

35. "Democracy and US Policy in Latin America," 126. See also Levine, Conflict and Political Change in Venezuela.

36. Schwartzberg, Democracy and U.S. Policy, 168.

37. Smith, America's Mission, 241; Huntington, The Third Wave, 92; Pastor, Exiting the Whirlpool, 138-139; Brands, Latin America's Cold War.

38. Kryzanek, US-Latin American Relations, 165-174; Lowenthal, Exporting Democracy, 388-395; Huntington, The Third Wave, 92; and Carothers, In the Name of Democracy.

39. These are the words of Ambassador (ret.) Edwin Corr. He served in Ecuador, Peru, and Bolivia during each respective transition. In his opinion, with the possible exception of Peru, these transitions would not have taken place as early as they did if it had not been for the US. Interview with the authors, January 26, 2018.

40. Lake, Hierarchy in International Relations.

41. Huntington, The Third Wave, 97.

42. Mainwaring and Pérez-Liñán, Democracies and Dictatorships, 229.

43. Pastor, Exiting the Whirlpool, 46.

44. Hartlyn, The Struggle for Democratic Politics in the Dominican Republic, 125; see also Atkins, Latin America and the Caribbean.

45. US Department of State, "Country Priorities in Latin America". These were countries where the US had important leverage. As Thomas Carothers recalls "in the 1980s the US had significant economic aid programmes only in Ecuador, Peru, Bolivia, and Colombia” (In the Name of Democracy, 136).

46. Interview with Ambassador (ret.) Edwin Corr, February 1, 2018.

47. Handelman and Sanders, Military Government, 46.

48. Pastor, Exiting the Whirlpool, 45.

49. Our evidence from interviews with US officials needs be taken with a grain of salt because actors involved in these processes might overemphasize their own role. Still, the norm of non-interference in domestic affairs and diplomatic confidentiality provide some checks on what US officials took credit for.

50. We thank one reviewer for this point.

51. US Department of State, "Security Assistance Reporting Requirement for Peru".

52. Interview with Ambassador (ret.) Harry Shlaudeman, December 11, 2015.

53. Carothers, In the Name of Democracy, 127.

54. Ibid., 128 .

55. Gamarra, The United States and Bolivia, 187.

56. O'Donnell and Schmitter, Transitions from Authoritarian Rule.

57. Mainwaring and Pérez-Liñán. Democracies and Dictatorships in Latin America.

58. See Thyne, "Supporter of Stability".

59. Kryzanek, US-Latin American Relations, 181-183; Carothers, In the Name of Democracy, 196; Hendrix, "USAID Promoting Democracy".

60. Mainwaring and Pérez-Liñán, Democracies and Dictatorships, 93-123.

\section{Acknowledgements}

We would like to thank Michael Coppedge, Benjamin García Holgado, Gary Goertz, Jeremy Graham, Tahir Kilavus, Tom Long, Laurie Nathan, Anibal Pérez-Liñan, and two reviewers of Democratization for their comments on previous versions. We are also grateful to Ambassadors (ret.) Edwing Corr, Tom Pickering, and Harry Shlaudeman for granting us many interviews, and to David Scott Palmer (in memoriam) who commented extensively on this work before his passing on 28 April 2018.

\section{Disclosure statement}

No potential conflict of interest was reported by the authors. 


\section{Notes on contributors}

Luis L. Schenoni is a $\mathrm{PhD}$ candidate in political science. His research bridges comparative politics and international relations and focuses on state formation; regime change; IR theory; and foreign policy analysis.

Scott Mainwaring is the Jorge P. Lemann Professor of Brazil Studies and the Faculty Co-chair of the Harvard Brazil Studies Program. His research focuses on democratic institutions and democratization; authoritarian and democratic regimes; and party systems.

\section{ORCID}

Luis L. Schenoni (D) http://orcid.org/0000-0001-6770-2136

\section{Bibliography}

Atkins, P. Latin America and the Caribbean in the International System. Boulder: Westview Press, 1999.

Brands, H. Latin America's Cold War: An International History. Cambridge, MA: Harvard University Press, 2010.

Brinks, D., and M. Coppedge. "Diffusion Is No Illusion: Neighbor Emulation in the Third Wave of Democracy.” Comparative Political Studies 39, no. 4 (2006): 463-489.

Brown, A. "Transnational Influences in the Transition From Communism." Post-Soviet Affairs 16, no. 2 (2000): 177-200.

Carothers, T. In the Name of Democracy: U.S. Policy Toward Latin America. Berkeley: University of California Press, 1993.

Coppedge, M. Democratization and Research Methods. New York: Cambridge University Press, 2012.

Gamarra, E. "The United States and Bolivia: Fighting the Drug War." In The United States and Latin America: The New Agenda, edited by J. Dunkerley and V. Bulmer Thomas, 177-206. Cambridge, MA: David Rockefeller Center for Latin American Studies, Harvard University, 1999.

Goertz, G. Multimethod Research, Casual Mechanisms, and Case Studies. Princeton: Princeton University Press, 2017.

Green, A., and R. Kohl. "Challenges of Evaluating Democracy Assistance: Perspectives From the Donor Side." Democratization 14, no. 1 (2007): 151-165.

Gunitsky, S. "From Shocks to Waves: Hegemonic Transitions and Democratization in the Twentieth Century." International Organization 68, no. 3 (2014): 561-597.

Handelman, H., and T. Griffin Sanders. Military Government and the Movement Toward Democracy in South America. Bloomington: Indiana University Press, 1981.

Hartlyn, J. The Struggle for Democratic Politics in the Dominican Republic. Chapel Hill: University of North Carolina Press, 1998.

Hendrix, S. "USAID Promoting Democracy and the Rule of Law in Latin America and the Caribbean." Southwest Journal of Law and Trade in the Americas 49 (2003): 277-320.

Huntington, S. The Third Wave: Democratization in the Late Twentieth Century. Norman: University of Oklahoma Press, 1991.

Kryzanek, M. “The 1978 Election in the Dominican Republic: Opposition Politics, Intervention, and the Carter Administration." Caribbean Studies 19 (1979): 51-73.

Kryzanek, M. US-Latin American Relations. New York: Praeger, 1990.

Lake, D. Hierarchy in International Relations. Ithaca: Cornell University Press, 2009.

Levitsky, S., and L. Way. Competitive Authoritarianism: Hybrid Regimes After the Cold War. New York: Cambridge University Press, 2010.

Lowenthal, A., ed. Exporting Democracy: The United States and Latin America. Baltimore: The Johns Hopkins University Press, 1991.

Mainwaring, S., and A. Pérez-Liñán. Democracies and Dictatorships in Latin America: Emergence, Survival, and Fall. New York: Cambridge University Press, 2013.

Middlebrook, K., and C. Rico, eds. The United States and Latin America in the 1980s. Pittsburgh: University of Pittsburgh Press, 1986. 
O’Donnell, G., and P. Schmitter. Transitions From Authoritarian Rule: Tentative Conclusions About Uncertain Democracies. Baltimore: Johns Hopkins University Press, 1986.

Owen, J. The Clash of Ideas in World Politics. Princeton: Princeton University Press, 2010.

Pastor, R. Exiting the Whirlpool: U.S. Foreign Policy Towards Latin America and the Caribbean. Boulder: Westview Press, 2001.

Pevehouse, J. Democracy From Above: Regional Organizations and Democratization. New York: Cambridge University Press, 2005.

Pridham, G. Encouraging Democracy: The International Context of Regime Transition in Southern Europe. New York: St. Martin's Press, 1991.

Rabe, S. Eisenhower and Latin America: The Foreign Policy of Anticommunism. Chapel Hill: University of North Carolina Press, 1988.

Reiter, D. "Foreign-Imposed Regime Change." Oxford Research Encyclopedia of Politics (2017). doi:10. 1093/acrefore/9780190228637.013.335.

Rioux, B., and Ch. Ragin. Configurational Comparative Methods. London: Sage, 2009.

Robinson, W. "Promoting Capitalist Polyarchy: The Case of Latin America." In American Democracy Promotion, edited by M. Cox, J. Ikenberry, and T. Inoguchi, 308-325. New York: Oxford University Press, 2000.

Schoultz, L. Beneath the United States: A History of U.S. Policy Toward Latin America. Cambridge: Harvard University Press, 1998.

Schwartzberg, S. Democracy and U.S. Policy in Latin America During the Truman Years. Gainesville: University Press of Florida, 2003.

Seawright, J. “Comment: Limited Diversity and the Unreliability of QCA.” Sociological Methodology 44 (2014): 118-121.

Smith, T. America's Mission: The United States and the Worldwide Struggle for Democracy in the Twentieth Century. Princeton: Princeton University Press, 1994.

Smith, P. Tallons of the Eagle: Dynamics of U.S.-Latin American Relations. New York: Oxford University Press, 2000.

Thyne, C. "Supporter of Stability or Agent of Agitation? The Effect of US Foreign Policy on Coups in Latin America." Journal of Peace Research 47, no. 4 (2010): 449-461.

US Department of State. "Country Priorities in Latin America." 1978. http://search.proquest.com. proxy.library.nd.edu/docview/1679039317/fulltextPDF/3B3766CAB07478BPQ/11?accountid= 12874.

US Department of State. "Security Assistance Reporting Requirement for Peru." Accessed May 24, 1980. https://search-proquest-com.proxy.library.nd.edu/docview/1679155534/4DAC903B02644D7 $\mathrm{EPQ} / 2$ ? accountid=12874.

Weyland, K. Making Waves: Democratic Contention in Europe and Latin America Since the Revolutions of 1848. New York: Cambridge University Press, 2014.

Whitehead, L., ed. The International Dimension of Democratization. New York: Oxford University Press, 1996. 